\title{
Health administration: from provision to the assessment of outcomes
}

\author{
Administração em saúde: da prestação à avaliação de resultados \\ Vasco Pinto dos Reis ${ }^{1} \&$ Pedro Andrade Kings ${ }^{2}$ \\ ${ }^{1}$ CBIOS - Research Center for Health Science and Technologies, Universidade Lusófona \\ Campo Grande 376, 1749-024 Lisboa PORTUGAL \\ ${ }^{2}$ Northern Lisbon Hospital Centre \\ Email: taniamafalda@hotmail.com
}

\begin{abstract}
The "health policy and administration" area has generated enormous interest in recent decades.

This is the result of several factors. First, there has been a substantial increase in health expenditure Secondly, the significant increase in the health status of populations worldwide has motivated "policy makers", academics, analysts and also the "media" to discuss health issues as key subjects with the intent to understand further the very complex healthcare process.

However it is difficult to quantify such improvements even though health costs and other financial data are often discussed. There is a a paucity of reliable data regarding outcomes (ie the impact of health care on the population's health) and so-called "health gains",despite the fact that these are major goals for any health system. Thus, it is difficult to relate the rise in heath care costs to the improvement in outcomes and hence develop a balanced view of the performance of the sector.. Therefore it is urgent to develop explicit, valuable and useful assessment models, in order to validate the provision efficiency and the effectiveness of achieved outcomes.

This study intends to contribute to this issue, through identifying a useful indicator that can be used objectively to describe "health gains" , in order to assess a heath system's performance. It will not be another outputs measure but rather it is aimed at solving long-standing problems. It looks to support the relation between expended resources and achieved outcomes and to detect changes and show differences.
\end{abstract}

Keywords: Health policy and administration; health outcomes; potential life lost years; health expenses

\begin{abstract}
Resumo
Aárea da "política e administração da saúde", tem merecido um interesse crescente nas últimas décadas.

Provavelmente em consequência do substancial aumento das despesas de saúde que tem ocorrido em todo o mundo mas, também porque se tem verificado uma sensível melhoria da situação de saúde das populações, o que faz com que, "policy makers", académicos, analistas do setor e "media" tragam as questões de saúde para as primeiras páginas, valorizando-as e tentando melhorar a compreensão sobre o muito complexo processo de prestação em saúde.

Não se trata no entanto de uma melhoria que usualmente seja quantificada, ocorrendo até que, se são frequentes, as tentativas de medir os custos e a produção da saúde, setor que tem uma importante dimensão económica, o mesmo não se verifica em relação aos seus resultados (o impacto que os cuidados tiveram na saúde das populações) e ainda menos em relação aos chamados "ganhos em saúde", afinal o objectivo maior dos sistemas de saúde.

Assim, entre a subida das despesas e a melhoria dos resultados, há uma falta de relacionamento que torna difícil fazer um balanço, pelo que é urgente adotar modelos de avaliação da prestação e dos seus resultados que sejam explícitos e ajudem a validar a efetividade da prestação e dos resultados obtidos.

O presente trabalho pretende ser um contributo para clarificar esta questão e procurar um indicador corrente que possa ser utilizado para objetivar os "ganhos em saúde" e que, por ser quantificável, possa permitir a definição de medidas de efetividade dos resultados obtidos e de avaliação da performance dos sistemas de saúde.

Não será mais uma medida de medição da produção (outputs) mas que pode resolver muitos problemas de há longos anos, e dar suporte ao confronto recursos/resultados e permitindo avaliar a performance de sistemas de saúde, com consistência face aos seus objectivos e fiabilidade, sendo capaz de detetar as mudanças e de mostrar as diferenças.
\end{abstract}

Palavras-chave: Política e Administração de Saúde; resultados em saúde; anos potenciais de vida perdidos; gastos em saúde 


\section{Introduction}

Winslow ${ }^{1}$ defined Health Administration as the science or art of preventing disease, prolonging life and promoting provision efficiency, by the organized effort, from the community, to clean up the environment, to control transmission diseases, to develop health education programs and to organise healthcare units. This is in order to ensure every citizen their right to health, including development of appropriate social mechanisms to guarantee the adequate living standard to maintain their health ${ }^{(1)}$. Winslow considered that the administration of health resulted from the application of managing methods and processes to achieve health goals in a community.

The administration is the core of all organized activity, being a prerequisite for social, economic, technological and human development and productivity. It has to consider a wide variety of factors that may influence, either positively or negatively, this development. This determines an increasingly wider intervention of the health administration, and requires more integrated approaches and intervention typologies ${ }^{(2)}$.

In fact, since Winslow's definition, a huge increase in the number and complexity of the functions to be included has been noted. This increase has not always been matched in terms of action, leading to an inequality between identified needs and performance.

There is no doubt that health has accumulated a long list of advantages in terms of care ${ }^{(3),(4)}$.

But, regardless of its successes and failures, it is now confronted with multiple social disturbances overpopulation, poverty, malnutrition, unemployment and unequal distribution of educational opportunities. These are all recognized as major factors that have an impact on health ${ }^{(5)}$.

Thus, the conventional treatment of disease and its prevention, which are essential for health promotion, are no longer adequate and we are now moving globally to a holistic view which embraces the needs of the whole community. In this case health care or health provisions are increasingly regarded as, "public assets", that, once produced, should be available to the entire community. This accords to the economist's concept of a "central asset" (e.g. an asset that not only meets individual needs but also gives satisfaction to the general needs of the population).

It is recognized that health facilities should not depend on the users' acquisition power. It follows then that health programs must ensure accessibility for all, including the poorest, regardless of their location ${ }^{(6 .)}$. In other words, people should feel that their health is protected. They should not have to face the possibility of financial ruin in order to maintain their personal health. The issue is particularly pertinent given the present widespread economic crisis which has put considerable pressure on incomes and is therefore becoming an important political issue. Thus the maintenance and restoration of health and more 10

\section{Introdução}

Winslow definiu Administração em Saúde como a ciência ou a arte de prevenir as doenças, prolongar a vida e promover a eficiência da prestação através do esforço organizado da comunidade para sanear o meio ambiente, controlar as doenças transmissíveis, desenvolver programas de educação para a saúde e organizar as unidades assistenciais de modo assegurar a cada cidadão a concretização do seu direito à saúde, incluindo o desenvolvimento de mecanismos sociais apropriados para garantia ao cidadão de padrões de vida adequados à manutenção da sua saúde ${ }^{(1)}$ Para ele, a administração de saúde era a aplicação dos métodos e dos processos da gestão à prossecução dos objetivos de saúde numa comunidade.

A administração está assim no centro de toda a atividade organizada e, portanto, também da saúde que, sendo um pré requisito do desenvolvimento social, económico, tecnológico e da produtividade humana, tem que se confrontar com uma ampla variedade de fatores que podem influenciar positiva ou negativamente esse desenvolvimento. O que, determina uma intervenção cada vez mais alargada da administração em saúde e a necessidade de abordagens integradas das questões de saúde, envolvendo cada vez mais tipologias de intervenção ${ }^{(2)}$.

De facto, desde que Winslow ensaiou aquela definição de administração de saúde, tem havido um enorme alargamento do número e da complexidade das funções que devem integrar a administração em saúde, alargamento que nem sempre tem tido correspondência em termos de ação, aumentando a desigualdade entre as necessidades identificadas e a performance alcançada.

Não há qualquer dúvida de que a Saúde tem acumulado uma longa lista de trunfos no que se refere à prestação de cuidados ${ }^{(3),(4)}$.

Mas, com todos os seus sucessos e falhas, também se confronta agora com múltiplas perturbações sociais: sobrepopulação, pobreza, má nutrição, desemprego e má distribuição das oportunidades educacionais, todas elas reconhecidas, hoje, como tendo fortes repercussões na saúde ${ }^{(5)}$.

Ultrapassa-se assim, não só a convencional cura das doenças mas também a sua prevenção e a promoção da saúde em geral e avança-se para a globalidade na atenção à comunidade.

De tal modo, que os cuidados ou as prestações de saúde são cada vez mais sentidos como aquilo a que os economistas chamam um "bem central" (bem que não só satisfaz necessidades individuais mas também dá satisfação a necessidades gerais da população), sendo ao mesmo tempo são sentidas e reconhecidas como "bens públicos", isto é, bens que, uma vez produzidos, se reivindica deverem estar disponíveis para toda a comunidade.

Reconhece-se pois hoje que as oportunidades de saúde não devem depender do poder de compra dos utentes e que, por outro lado, os programas de Saúde têm que garantir a acessibilidade de todos, incluindo os mais desfavorecidos, independentemente da sua localização ${ }^{(6)}$.

Por outras palavras, as populações sentem cada vez mais que a sua saúde deve ser protegida da escolha dramática entre a ruína financeira ou a perca daquele bem precioso o que, neste momento de crise económica generalizada, transformou a manutenção e a recuperação da saúde e mais genericamente 
generally the "health gains" are major goals of health systems in most countries.

Enthoven and Kronick noted that health systems were "full paradox of excess and deficiency" (7) as early as 1989 and this situation continues today.

Using examples from EU countries concerning health expenses and results we can explore the contradictions of the Enthoven and Kronick paradox.

Let us start by health expenses.

Table $1{ }^{(8)}$ shows the evolution between 1990 and 2009 in some EU countries, of : (a) the total health expenditure (THE) as a percentage of gross domestic product (GDP) (\% DTS / GDP), (b) Public health expenses (PHE) as a percentage of THE (\% PHE/THE) and (c)THE per capita In \$ PPP(THE/\$PPPs). os "ganhos em saúde" num objetivo maior dos sistemas de saúde da generalidade das sociedades.

Continuamos pois "em pleno paradoxo de excessos e carência" como já em 1989 Enthoven e Kronick chamavam aos sistemas de saúde ${ }^{(7)}$.

Breves comentários sobre as despesas com a saúde e sobre alguns resultados obtidos em países da União Europeia, permitirão, explicitar o sentido de contradição da expressão que Enthoven e Kronick utilizam para qualificar os sistemas de saúde.

Comecemos então pelas despesas com a saúde.

A Tabela $1^{(8)}$ mostra a evolução, entre 1990 e 2009, em alguns países da União Europeia, das despesas totais de saúde (DTS) em percentagem do produto interno bruto (PIB) (\% DTS/PIB) (a), das despesas públicas de saúde (DPS) em percentagem das DTS (\% DPS/DTS) (b) e das DTS per capita, em \$PPP (DTS/\$PPP) C .

Table 1 - European Union Countries / \% THE/GDP (a), \% PHE/THE (b) e THE percapita - in \$PPPs (c) / Evolution 1990/2009

Tabela 1 - Evolução da \% DTS/PIB (a), \% DPS/DTS (b) e DTS percapita - em \$PPPs (c) (1990/2009)

\begin{tabular}{|c|c|c|c|c|c|c|c|c|c|}
\hline \multirow{3}{*}{ Countries / Países } & \multicolumn{3}{|c|}{$\begin{array}{l}\% \text { THE/GDP (a) } \\
\% \text { DTS/PIB (a) }\end{array}$} & \multicolumn{3}{|c|}{$\begin{array}{l}\% \text { PHE/THE (b) } \\
\% \text { DPS/DTS (b) }\end{array}$} & \multicolumn{3}{|c|}{$\begin{array}{l}\text { THE percapita - in \$PPPs (c) } \\
\text { DTS percapita - em \$PPPs (c) }\end{array}$} \\
\hline & & & & & & & & & \\
\hline & 1990 & 2000 & 2009 & 1990 & 2000 & 2009 & 1990 & 2000 & 2009 \\
\hline Belgium & 7,2 & 8,1 & 10,9 & - & 74,6 & 75,1 & 1353 & 2245 & 3946 \\
\hline Czech Republic & 4,7 & 6,5 & 8,2 & 97,4 & 90,3 & 84,0 & 558 & 981 & 2108 \\
\hline Denmark & 8,3 & 8,7 & 11,5 & 82,7 & 83,9 & 85,0 & 1540 & 2508 & 4348 \\
\hline Estonia & - & 5,3 & 7,0 & - & 77,2 & 75,3 & - & 522 & 1393 \\
\hline Finland & 7,7 & 7,2 & 9,2 & 80,9 & 71,3 & 74,7 & 1363 & 1853 & 3226 \\
\hline France & 8,4 & 10,1 & 11,8 & 76,6 & 79,4 & 77,9 & 1445 & 2553 & 3978 \\
\hline Germany & 8,3 & 10,3 & 11,6 & 76,2 & 79,8 & 76,9 & 1764 & 2669 & 4218 \\
\hline Greece & 6,6 & 7,9 & & 53,7 & 60,0 & - & 845 & 1451 & - \\
\hline Hungary & - & 7,0 & 7,4 & - & 70,7 & 69,7 & - & 853 & 1511 \\
\hline Italy & 7,7 & 8,1 & 9,5 & 79,5 & 72,5 & 77,9 & 1355 & 2064 & 3137 \\
\hline Luxembourg & 5,4 & 7,5 & 7,8 & 93,1 & 85,1 & - & - & 3268 & 4808 \\
\hline Netherlands & 8,0 & 8,0 & 12,0 & 67,1 & 63,1 & - & 1412 & 2340 & 4914 \\
\hline Poland & 4,8 & 5,5 & 7,4 & 91,7 & 70,0 & 72,2 & 289 & 583 & 1394 \\
\hline Portugal & 5,7 & 9,3 & & 65,5 & 66,0 & - & 628 & 1654 & - \\
\hline Slovak Republic & - & 5,5 & 9,1 & - & 89,4 & 65,7 & - & 604 & 2084 \\
\hline Slovenia & - & 8,3 & 9,3 & & 74,0 & 73,4 & - & 1453 & 2579 \\
\hline Spain & 6,5 & 7,2 & 9,5 & 78,7 & 71,6 & 73,6 & 870 & 1537 & 3067 \\
\hline Sweden & 8,2 & 8,2 & 10,0 & 89,9 & 84,9 & 81,5 & 1592 & 2286 & 3722 \\
\hline United Kingdom & 5,9 & 7,0 & 9,8 & 83,6 & 79,2 & 84,1 & 960 & 1828 & 3487 \\
\hline
\end{tabular}

OECD Health Data, $2011^{\left({ }^{(8)}\right.}$ 
It includes data, and countries that, could be considered "stabilized market economies", even before the referred period, and data from countries that changed (sometimes dramatically) during that period, both in their social and political organization, including the structure of their health systems .

A quick look at this data confirms that all the concerns about health expenses progression in the European Union are justified. In fact, in all countries, regardless of their current development status and its model of social and political organization, the wealth share devoted to health (\% DTS / GDP) (the) strongly increased, both over the entire period, and during each decade. There is no country where the increase in $\%$ THE / GDP (a) percentage is not expressed in two digits. This applied equally to countries that at the beginning of the period were already "stabilized market economies", and also those referred to as "Central Europe" or "Eastern Europe" countries that, during the period, experienced structural change.

Concerning the (\% PHE/ THE) (b) relationship, it is clear that growth was much more moderate, maybe because in both groups of countries health financing systems in Europe were already predominantly public by the early 90 's.

But the growth of health spending comes again and exuberantly through another approach.

When analysing the THE per capita in \$ PPPs"(DTS per capita - In \$ PPP) (c), and allowing for the fact that the effect of variance in population size is eliminated in this index, we find that during the referred period in all the listed countries, the \% of growth of THE per capita (In constant prices in \$PPC) usually reaches three digits and is never less than $100 \%$ in any country.

This applies to both groups; the "stabilized market economies" and those countries experiencing changes in their social and political organization, including the respective health systems structure, during the period. This finding with regard to the growth in total health care expenditures (THE), particularly when compared with the generated wealth within the respective countries, corresponds to the research results reported by Enthoven and Kronick ${ }^{(7 .)}$ This, obviously, raises questions about what has happened from the outcomes (health gains) perspective, to justify such an expense with this magnitude and pace of growth?

\footnotetext{
${ }^{1}$ WINSLOW, C.-E. AMORY (1877/1957). After many years as a professor of Public Health at Yale University, he is still considered one of the founders of modern public health, not only in the U.S. but also in the "western world" as it was then called. Winslow was the pioneer of a holistic perspective on health that spread through his teaching and he published dozens of papers.

Purchasing Power Parities (\$ PPPs) are account units that, simultaneously and through a currency conversion, try to translate to a single currency (U.S. dollars in this case) the purchasing power of different currencies. In other words, they seek to eliminate the differences between price level and value of the currencies in a given group of countries.

${ }^{3}$ Belgium, Denmark, Finland, France, Germany, Greece, Italy, Luxembourg, Netherlands, Spain, Portugal, Sweden and UK

${ }^{4}$ Czech Republic, Estonia, Hungary, Poland, Slovakia and Slovenia 12
}

Inclui dados, quer de países que, já antes do período considerado, poderiam ser considerados como "economias de mercado estabilizadas", quer de países que, durante esse período, sofreram mudanças (em alguns casos bastante acentuadas) na sua organização social e política e na estrutura dos seus sistemas de saúde.

Uma análise, mesmo que sumária deste dados confirma serem justificadas, para a União Europeia, as preocupações expressas sobre a evolução das despesas com a saúde.

De facto, em todos os países, independentemente do seu desenvolvimento atual e do seu modelo de organização social e política no inicio do período, a parte da riqueza produzida dedicada à saúde, (\% DTS/PIB) (a), cresceu fortemente, quer considerando todo o período, quer considerando, separadamente, cada uma das décadas.

Não há nenhum país onde a percentagem do aumento da \% DTS/PIB (a) não se expresse em dois dígitos.

Isto, não só nos países que no início do período já eram "economias de mercado estabilizadas", mas também naqueles que, durante o período, conheceram mudanças estruturais, sendo mesmo conhecidos, no início do período, como países da "Europa Central" ou da "Europa de Leste".

Já no que se refere à relação (\% DPS/DTS) (b) e talvez porque, o financiamento dos sistemas de saúde na Europa já fosse, na década de 90, predominantemente público em qualquer dos dois grupos de países, o crescimento (que também se revela), foi muito mais moderado.

Mas o crescimento das despesas de saúde volta a manifestar-se e exuberantemente, através de outro tipo de abordagem.

Quando se analisa a DTS per capita em \$PPPs" (DTS per capita - em \$PPPs) (c), valorizando a população (o que tem até algum efeito de padronização, já que elimina ou reduz disparidades associadas à dimensão da população), verifica-se que, durante o período considerado e em todos os países referidos, a \% de crescimento das DTS per capita (em preços constantes em \$PC), atinge geralmente os três dígitos e que, em, nenhum país, é inferior a $100 \%$.

O que, mais uma vez, acontece, quer nos países com "economias de mercado estabilizadas" no início do período, quer em países que, durante o período, tiveram mudanças na sua organização social e política e na estrutura dos seus sistemas de saúde.

Isto é, no que se refere ao crescimento das despesas totais de saúde (DTS), em particular quando as comparamos com a riqueza produzida a nível do respetivo país, parece estar localizado um dos excessos que Enthoven e Kronick referiam ${ }^{(7)}$.

O que, naturalmente, levanta questões sobre o que terá acontecido, do ponto de vista dos resultados, (isto é, dos ganhos em saúde), com uma despesa com este volume e com este ritmo de crescimento.

WINSLOW, C-E. AMORY (1877/1957). Depois de muitos anos como professor de Saúde Pública na Yale University, é ainda hoje considerado como um dos fundadores da moderna Saúde Pública, não só nos Estados Unidos como no "mundo oocidental" como então era designado. Winslow foi o pioneiro de uma perspetiva holística da saúde que difundiu através do seu ensino e das dezenas de trabalhos que publicou.

${ }^{2}$ Purchasing Power Parities (\$PPPs) são unidades de conta que, simultaneamente e através de uma conversão monetária, procuram traduzir para uma moeda única (no caso o dólar americano) e tentam parificar o poder de compra de diferentes moedas. Por outras palavras, procuram eliminar as diferenças entre níveis de preço e valor das moedas de um grupo de países.

${ }^{3}$ Bélgica, Dinamarca, Finlândia, França, Alemanha, Grécia, Itália, Luxemburgo, Holanda, Espanha, Portugal, Suécia e Reino Unido.

${ }^{4}$ República Checa, Estónia, Hungria, Polónia, Eslováquia e Eslovénia 
We need to examine what might have happened in these countries from this point of view.

European citizens (and probably others) seem to have reasons to be concerned about their expensive healthcare systems. But they should also be satisfied with the progresses made during the period.

Under this view Table $2^{(8)}$ shows, for the same European Union countries, in the same period and for both sexes, the "life expectancy at birth" (Lex) (a), the "infant mortality per 1000 live births" - (I Mort.) (b) and consultation number "per capita" (Cons. per capita) (C).)
Vejamos então, numa curta análise o que terá ocorrido nestes países sob esse ponto de vista.

Os cidadãos europeus (e provavelmente não só), parecem ter razões para estar preocupados com os seus (aparentemente) dispendiosos sistemas de saúde, mas também têm motivos para estar satisfeitos com o progresso registado durante o período.

Nesta perspetiva a Tabela $2^{(8)}$ mostra, para os mesmos países da União Europeia, a evolução no mesmo período e para ambos os sexos, da "esperança de vida à nascença" (EVN) (a), da "mortalidade infantil por 1000 nados-vivos" - (Mort. Inf) (b) e do "número de consultas per capita” (Cons. per capita) (C)

Table 2 - European Union Countries - Lex (a), Inf Mort (b) percapita Cons (c) Evolution 1990/2009

Tabela 2 - Países da União Europeia - Evolução da EVN (a), Mort Inf (b) Cons/percapita) (c) (1990/2009)

\begin{tabular}{|c|c|c|c|c|c|c|c|c|c|}
\hline \multirow[t]{2}{*}{$\begin{array}{c}\text { Countries } \\
\text { Países }\end{array}$} & \multicolumn{3}{|c|}{$\begin{array}{l}\text { Lex (a) } \\
E V N(a)\end{array}$} & \multicolumn{3}{|c|}{$\begin{array}{c}\text { Inf Mort (b) } \\
E V N(a),\end{array}$} & \multicolumn{3}{|c|}{$\begin{array}{c}\text { Percapita/ } \\
\text { Consultations (c) } \\
\text { Cons/percapita (c) }\end{array}$} \\
\hline & 1990 & 2000 & 2009 & 1990 & 2000 & 2009 & 1990 & 2000 & 2009 \\
\hline Belgium & 76,1 & 77,8 & 80 & 8,0 & 4,8 & 3,4 & 7,7 & 7,9 & - \\
\hline Czech Republic & 71,5 & 75,1 & 77,3 & 10,8 & 4,1 & 2,9 & 7,7 & 7,9 & - \\
\hline Denmark & 74,9 & 76,8 & 79 & 7,5 & 5,3 & 3,1 & 3,7 & 4,2 & 4,6 \\
\hline Estonia & 69,6 & 70,6 & 75 & 12,3 & 8,4 & 3,6 & - & 6,3 & 6,3 \\
\hline Finland & 75 & 77,7 & 80 & 5,6 & 3,8 & 2,6 & 3,9 & 4,3 & 4,2 \\
\hline France & 76,8 & 79 & 81 & 7,3 & 4,5 & 3,9 & 5,9 & 6,9 & 6,5 \\
\hline Germany & 75,3 & 78,2 & 80,3 & 7,0 & 4,4 & 3,5 & - & 7,2 & 8,2 \\
\hline Greece & 77,1 & 78 & 80,3 & 9,7 & 5,9 & 3,1 & 4,3 & 4,3 & - \\
\hline Hungary & 69,4 & 71,7 & 74 & 14,8 & 9,2 & 5,1 & - & 11,1 & 12,0 \\
\hline Italy & 77,1 & 79,8 & .. & 8,1 & 4,3 & 3,7 & - & 6,1 & - \\
\hline Luxembourg & 75,5 & 78 & 80,7 & 7,3 & 5,1 & 2,5 & - & 6,1 & 6,3 \\
\hline Netherlands & 77 & 78 & 80,6 & 7,1 & 5,1 & 3,8 & 5,5 & 5,9 & 5,7 \\
\hline Poland & 70,7 & 73,8 & 75,8 & 19,3 & 8,1 & 5,6 & 5,8 & 5,4 & 6,8 \\
\hline Portugal & 74,1 & 76,7 & 79,5 & 10,9 & 5,5 & 3,6 & 3,0 & 3,5 & 4,1 \\
\hline Slovak Republic & 71 & 73,3 & 75 & 12,0 & 8,6 & 5,7 & - & 15 & - \\
\hline Slovenia & 73,3 & 75,5 & 79 & 8,4 & 4,9 & 2,4 & - & - & 6,6 \\
\hline Spain & 77 & 79,4 & 81,8 & 7,6 . & 4,4 & 3,3 & - & - & 7,5 \\
\hline Sweden & 77,6 & 79,7 & 81,4 & 6,0 & 3,4 & 2,5 & 2,8 & 2,8 & 2,9 \\
\hline United Kingdom & 75,7 & 77,9 & 80,4 & 7,9 & 5,6 & 4,6 & 6,1 & 5,3 & 5,0 \\
\hline
\end{tabular}

OECD Health Data, $2011^{(8)}$ 
Table 3 - European Union Countries, (Lex) (a), Healthy Life Years (HLY) (b) Lex/ HLY (c) (man) Evolution $2008 / 2010$ Tabela 3 - Países da União Europeia, Evolução da (E.V.Nasc.) (a), (E.V.L Inc.) (b), (\%EVNasc/EVL. Inc.) (c) (homens) Evolução 2008/2010

\begin{tabular}{|c|c|c|c|c|c|c|c|c|c|}
\hline \multirow[t]{2}{*}{ Countries / Países } & \multicolumn{3}{|c|}{$\begin{array}{c}(\text { Lex) (a) } \\
\text { E.V.Nasc.) (a) }\end{array}$} & \multicolumn{3}{|c|}{$\begin{array}{l}\text { HLY (b) } \\
\text { E.V.L Inc. (b) }\end{array}$} & \multicolumn{3}{|c|}{$\begin{array}{c}\% \text { Lex/ HLY (c) } \\
\% \text { EVNasc/EVL Inc (c) }\end{array}$} \\
\hline & 2008 & 2009 & 2010 & 2008 & 2009 & 2010 & 2008 & 2009 & 2010 \\
\hline Austria & 75,6 & 78,2 & 80,4 & 58,3 & 59,5 & 59,3 & 75,0 & 76,7 & 76,1 \\
\hline Belgium & 76,1 & 77,8 & 80 & 63,3 & 64,0 & - & 82,3 & 82,8 & - \\
\hline Czech Republic & 71,5 & 75,1 & 77,3 & 61,2 & 61,1 & 62,2 & 82,7 & 82,3 & 83,5 \\
\hline Denmark & 74,9 & 76,8 & 79 & 62,1 & 61,3 & 62,3 & 81,1 & 79,7 & 80,7 \\
\hline Estonia & 69,6 & 70,6 & 75 & 53,0 & 55,2 & 54,0 & 77,2 & 79,1 & 76,4 \\
\hline Finland & 75 & 77,7 & 80 & 58,6 & 58,1 & 58,5 & 76,7 & 75,8 & 76,0 \\
\hline France & 76,8 & 79 & 81 & 62,2 & 62,7 & 61,9 & 80,6 & 80,4 & 79,1 \\
\hline Germany & 75,3 & 78,2 & 80,3 & 56,3 & 57,1 & 57,9 & 72,6 & 73,4 & 74,3 \\
\hline Greece & 77,1 & 78 & 80,3 & 65,8 & 66,0 & 66,4 & 84,7 & 84,9 & 84,7 \\
\hline Hungary & 69,4 & 71,7 & 74 & 54,8 & 55,8 & 56,4 & 78,4 & 79,4 & 79,7 \\
\hline Ireland & 74,9 & 76,6 & 80 & 63,5 & 63,6 & 65,9 & 81,6 & 82,2 & 83,8 \\
\hline Italy & 77,1 & 79,8 &.. & 63,0 & 63,4 & - & 79,6 & 79,9 & - \\
\hline Luxembourg & 75,5 & 78 & 80,7 & 64,8 & 65,5 & 64,5 & 83,0 & 83,9 & 82,8 \\
\hline Malta & 76,9 & 77,8 & 79,1 & 68,9 & 69,6 & 70,2 & 89,6 & 89,4 & 88,6 \\
\hline Netherlands & 77 & 78 & 80,6 & 62,4 & 61,7 & 61,1 & 79,6 & 78,5 & 77,4 \\
\hline Poland & 70,7 & 73,8 & 75,8 & 58,5 & 58,3 & 58,5 & 82,2 & 81,5 & 81,1 \\
\hline Portugal & 74,1 & 76,7 & 79,5 & 59,1 & 58,2 & 59,2 & 77,6 & 76,0 & 77,1 \\
\hline Slovak Republic & 71 & 73,3 & 75 & 52,1 & 52,4 & 52,3 & 73,5 & 73,4 & 73,0 \\
\hline Slovenia & 73,3 & 75,5 & 79 & 59,5 & 60,5 & - & 78,7 & 79,7 & - \\
\hline Spain & 77 & 79,4 & 81,8 & 64,1 & 62,8 & 64,3 & 81,9 & 79,8 & 81,3 \\
\hline Sweden & 77,6 & 79,7 & 81,4 & 69,4 & 70,7 & 71,7 & 87,6 & 89,0 & 90,0 \\
\hline United Kingdom & 75,7 & 77,9 & 80,4 & 65,0 & 65,1 & - & 83,5 & 83,1 & - \\
\hline $\mathbf{E U ^ { ( 2 7 ) }}$ & 76,4 & 76,7 & - & 61,1 & 61,3 & - & 80,0 & 79,9 & - \\
\hline
\end{tabular}

OECD Health Data, $2011^{(8)}$

Eurostat Healthy Life years statistics (April 2011)

http://epp.eurostat.ec.europa.eu/statistics_explibed/index.php?title=He.(9).

These data are strongly qualified by Table $3^{(9)}$ which brings to the discussion, through the "life expectancy without incapacity" indicator (HLY) (b) a qualitative dimension that data from Tabela 2 (a) and the first column of Table 3 (a) don't allow.

This Table 3 uses a statistical index only recently released by Eurostat, "life expectancy without disabilities" (HLY) (b.)

Created in the European Union (and published by the Eurostat) within the "Lisbon Strategy" (2000/2010), it seeks to extend the concept of life expectancy to morbidities and disabilities, offering to the disease burden a qualitative dimension that is absent in the classical "life expectancy at birth" indicator (9).
Dados que são fortemente qualificados pelo conteúdo da Tabela $3{ }^{(9)}$ que, através do indicador "esperança de vida sem incapacidade" (b) permite introduzir na discussão uma dimensão qualitativa que os dados da Tabela 2 (a) e da primeira coluna da Tabela 3 (a) não têm.

Esta Tabela 3 utiliza um instrumento estatístico só recentemente divulgado pelo EUROSTAT: a "esperança de vida sem incapacidades" (EVS/Incap) (b).

Criado no âmbito da União Europeia (e divulgado pelo Eurostat) no Tabelada "estratégia de Lisboa" (2000/2010) e procura estender o conceito de esperança de vida às morbilidades e às incapacidades, dispondo de uma dimensão qualitativa sobre o peso da doença que o indicador esperança de vida à nascença não tem ${ }^{(9)}$. 
Lex (a) which already figured in Table 2 (a) is presented with data for three years $(2008,2009$ and 2010) and referred to males. Data for (HLY) (b) is presented in the second group of three columns, showing a different qualitative meaning. For Portugal, as an example, in 2010, 59.2 years out of Lex 79.5 years are "disability-free", which gives another meaning to the indicator. In Hungary, also in 2010, only 56.4 years out of 74 years of "life expectancy at birth," are enjoyed without disabilities. And in Denmark, 62.3 years out of 79-years of "life expectancy at birth" are enjoyed without disabilities. The last column in the group (c) shows for these three years, the relationship between the "life expectancy at birth" (Lex) and the "life expectancy without incapacity" (HLY), measured in percentage (\%) (c.) It is clear that only 10 of the 27 listed countries do not show a positive change (i.e. the $\%$ of "life expectancy free of disability" does not improve compared with the previous year).

These are three indicators of population health status which are generally accepted as significant "health gains". These show that those EU countries spending more money, predominantly public ${ }^{5}$, on health care, are at the same time the best places to be born, to live longer and to enjoy a better quality of life, with better access to health care (here represented by the physician's consultation per capita).

In fact, in just twenty years:

There was a general reduction of INF Mort. The data shows that only 3 of 19 countries experienced a reduction of less than $50 \%)^{6}$. This reduction was accentuated in the last decade of the period in which all countries continued to reduce the INF. MORT, confirming that EU is the best place to be born. But the data does not allow any distinction between countries already "stabilized" in terms of market economies and those which have changed during these twenty years, either in their models of social and political organization, or in the structure of their respective health systems.

- There was also a general increase in life expectancy and, in the three years shown in Table 3 there was a better quality of life (without disabilities).

- $\quad$ There is an increased use of health systems as measured by the medical consultations per inhabitant, although the data shows less homogeneity than the other indicators. Nevertheless, this has to be understood as an improvement in the access to the health systems.
Com dados apenas referentes a apenas 3 anos (2008, 2009 e 2010) e ao sexo masculino, apresenta nas três primeiras colunas a EVN que já constava do Tabela 2 (a). No segundo grupo de três colunas aparecem os dados referentes (EVS/Incap) (b) que, naturalmente, têm um outro significado em termos qualitativos.

Para Portugal por exemplo e quanto ao ano de 2010, observa-se que, dos 79,5 anos de EVN, 59,2 são "livres de incapacidade" o que confere ao indicador um outro sentido. Já na Hungria, também em 2010, regista-se que dos 74 "anos de esperança de vida à nascença", só 56,4 anos são gozados sem incapacidades.

E, que, na Dinamarca, dos 79 anos de "esperança de vida à nascença", 62,3 anos, são gozados sem incapacidade,

E a última coluna do último grupo de três (c) apresenta para os três anos sob análise a relação entre a "esperança de vida à nascença" e a "esperança de vida sem incapacidade", medida em termos percentuais $(\%)(\mathbf{c})$.

E verifica-se que, só em 10 dos 27 países listados é que a evolução registada NÃO tem uma variação positiva (isto é, a \% de "esperança de vida livre de incapacidade" não melhora em relação ao ano anterior).

São três indicadores da situação de saúde de uma população geralmente aceites como significativos de "ganhos em saúde", e dos quais resulta que, se naqueles países da União Europeia se gasta cada vez mais dinheiro com a saúde e se esse dinheiro, segundo o modelo de financiamento mais frequente nesta parte do mundo é, predominantemente, de origem pública ${ }^{5}$, hoje e em contrapartida, se nasce em melhores condições, se vivem mais anos e com melhor qualidade de vida e houve melhoria no acesso aos cuidados de saúde tendência (aqui representada pelas consultas médicas porhabitante).

De facto, em apenas vinte anos:

- $\quad$ Houve uma generalizada redução da MORT INF (só em 3 dos 19 países cujos dados são apresentados, a redução registada durante o período não baixou para menos de metade) ${ }^{6}$. E a redução até se acentua na última década do período, em que todos os países cujos dados são apresentados, continuam a reduzir a MORT INF., o que justifica a afirmação feita de que se nasce em melhores condições na União Europeia. Aqui, os dados não permitem qualquer distinção entre os países que já eram "economias de mercado estabilizadas" e aqueles que durante estes vinte anos, tiveram mudanças, quer nos seus modelos de organização social e política, quer na estrutura dos seus sistemas de saúde;

Houve também um generalizado prolongamento da vida (vivem-se mais anos) e, pelo menos nos três anos apresentados no 


\section{valuation of the performance of health systems: a necessity}

This health spending and the outcomes situation briefly described, is actually a difficult challenge to communities trying to relate expenditure and benefits. It also poses problems when making comparisons between countries or between different periods in the same country.

This is primarily because there is no consensus, about measurement units that could be used to allow such comparisons. Even when some consensus emerges, procedures are extremely difficult, requiring data that barely exists, difficult to access and demanding complex evaluation routines.

Some indicators of cost, productivity and health outcomes are available for analysis. However, there is a serious lack of data concerning the full extent of changes and outcomes, and the cause / effect relationships between expenditure, productivity, and above all, health gains. For these reasons it is frequently found that, along with highly positive references to health systems, that there are critical commentaries which focus on the growth rate of health spending. These criticisms stress the inequalities that still mark the access to facilities, raising doubts about the quality of some of the services and questioning the extent to which these poor results are justified by the level of expenditure.

If we consider social issues and their relation to health, they demand better and more objective analysis as they are conditioned by values ${ }^{(10)}$ which themselves affect analytical approaches, hindering the creation of assessment conditions, and affecting almost all the health systems' components ${ }^{(11)}$. Therefore, any analysis or evaluation of health policy issues should consider the influence of values. This is likely to lead to clashes between personal and institutional values that in fact are manifestations of wider ethical positions ${ }^{(2)}$. This also means that, regardless of this concern with these major factors in the health sector (expenditure, production and outcomes) an additional effort must be directed to develop metrics and models to provide a joint quantifiable assessment of these factors ${ }^{(11,12 .)}$ Such a procedure would allow a systematic evaluation, supported by available data and by accessible procedures in the technical and financial perspective ${ }^{(13) .}$ In a period of economic crisis suitable methods of the evaluation of health systems' performance are particularly valuable because they help generate appropriate health gains ${ }^{(5)}$.

\footnotetext{
${ }^{5}$ The funding supported by compulsory social insurance systems is generally classified as public because it is mandatory.

${ }^{6}$ France, Germany and the UK in 1990 already had very low infant mortality.
}

Tabela 3 com melhor qualidade de vida (sem incapacidades);

- $\quad$ Houve igualmente embora neste caso sem a homogeneidade registada para outros indicadores, um aumento da utilização dos sistemas de saúde (no caso as consultas médicas por habitante) o que se interpreta como um melhor acesso aos sistemas de saúde.

\section{Avaliação da performance dos sistemas de saúde: uma necessidade}

A situação atrás apontada nesta síntese sobre gastos e "ganhos em saúde", despertou nas comunidades um "desafio" difícil, para permitir contrapor os gastos feitos com os benefícios obtidos, quer comparando países, quer, considerando o mesmo país em diferentes períodos.

Isto porque não há consenso tão generalizado quanto desejável, pelo menos no plano técnico, sobre unidades de medida que permitam sustentar aquelas comparações e porque, quando há alguma consensualização, os procedimentos a desenvolver são em geral extremamente complexos e os dados que requerem são raros, pouco acessíveis e introdução em rotinas de avaliação, muito difícil.

Isto é, conhecem-se os gastos, conhece-se a produção, conhecem.se alguns indicadores que se consideram ser de resultados mas, a total extensão das mudanças e as relações causa/efeito dos gastos, quer com a produção, quer sobretudo com os ganhos em saúde obtidos, não tem sido nem direta nem sistematicamente apreensível.,

E, também por isso, é frequente encontrar, ao lado de referências altamente positivas aos sistemas de saúde, outras muito críticas, incidindo sobre o ritmo de crescimento das despesas com a saúde, sublinhando desigualdades que ainda marcam o acesso às prestações, suscitando dúvidas sobre a qualidade de algumas dessas prestações e, sobretudo, interrogações sobre a eficiência dos gastos, isto é, sobre se, para obter (pelo menos) idênticos resultados, será indispensável aquele volume de despesa.

Ao que acresce o facto das questões sociais, designadamente as relacionadas com a saúde, terem uma característica que impõe a maior objetividade na sua análise uma vez que, são condicionadas por valores ${ }^{(10)}$ que influenciando as abordagens, e dificultando a criação de condições de rigorosas de apreciação e marcam quase todos as componentes dos sistemas de saúde ${ }^{(11)}$

5 o financiamento suportado por sistemas de seguro social obrigatório (exatamente porque é obrigatório) é regra geral classificado como público.

${ }^{6}$ França, Alemanha, e Reino Unido que em 1990 já apresentavam taxas de mortalidade infantil bastante baixas. 
In addition, it is only through this approach that we can find answers to a lot of significant issues that are currently unresolved and are important for those who finance the sector (e.g. citizens / taxpayers, consumers and insurers), and policy makers. Despite the idea that health care is expensive, this is the only way to demonstrate that it improves effectively the health status of the population. This enables the establishment of a cause effect relationship for every political decision, therefore providing an effective decision framework for health policy ${ }^{(14) .}$

We must therefore answer two apparently simple but essential questions, which are:

a) In terms of the health status of the population, are we better today or worse than yesterday?

b) Do countries with a similar level of health expenditure to ours have a similar level of health care status.
Por isso qualquer análise ou avaliação de uma política de saúde, deve reter esta influência dos valores que leva a choques entre posições (pessoas e entidades) que afinal não são mais do que manifestações de posições mais vastas ${ }^{(2)}$. $\mathrm{O}$ que significa também que, existindo um esforço de aprofundamento da reflexão sobre os grandes fatores de preocupação existentes no setor da saúde (despesas, produção e resultados) esse esforço terá que ser urgentemente completado com o desenvolvimento de métricas e modelos que permitam uma avaliação conjunta desses fatores, se possível quantificada e fiável sobre a efetividade e a eficiência dos resultados. ${ }^{(11),(12) .}$

Processos que, deverão permitir uma sua utilização sistemática para o que terão que recorrer a dados disponíveis e a procedimentos que sejam acessíveis quer no plano técnico, quer no plano financeiro ${ }^{(13)}$.

É que, a avaliação e promoção da performance na prestação de cuidados de saúde são, muito provavelmente, dos raros instrumentos que, no atual Tabelade crise económica que atinge fortemente os sistemas de saúde, podem ser utilizados para gerar acréscimos dos "ganhos em saúde" que afinal são o objetivo maior dos sistemas de saúde ${ }^{(5)}$.

Mas também, porque só por essa via será possível, encontrar respostas para uma série de questões que hoje não a têm (pelo menos em plano satisfatório) e dar garantias aos pagadores em geral (cidadãos/ contribuintes, utentes e seguradores) e policy makers que, apesar da prestação de cuidados de saúde ser dispendiosa, melhora a situação de saúde da população (é efetiva) consome apenas os recursos justamente necessários (é eficiente), podendo apurar-se a existência de causalidade entre as medidas de política de saúde adotadas (traduzam-se ou não em cuidados de saúde) e alterações (para melhor ou para pior) que sejam identificadas ${ }^{(14) .}$

Há pois que dar resposta a questões, aparentemente simples mas essenciais, do tipo:

a) Em termos de situação de saúde da população, hoje estamos melhor ou pior do que ontem?

b) Estamos melhor ou pior do que os países que gastam tanto como nós?

\section{Podem-se medir os resultados em saúde?}

A resposta é positiva, reconhecendo-se no entanto que não é uma questão de resposta fácil e única e sobretudo que se possa considerar como uma questão encerrada ${ }^{(11)}$.

Por um lado, para compreender uma realidade é necessário ter a capacidade de a medir o que exige uma unidade de medida, um instrumento de medida e um método, isto é, um conjunto de procedimentos que permita operacionalizar a ação.

Por outro lado, a avaliação da performance dos sistemas de saúde, sendo um dado essencial para a correta formulação das políticas de saúde e para, em sistemas vastos e complexos, saber quais as partes do sistema que melhor executam e quais são as menos positivas no desempenho do conjunto, não é uma tarefa linear.

É que, não há uma medida única da situação de saúde, quer para um indivíduo quer ainda menos para uma população ou para um grupo já que a saúde é um conceito satisfaction aspects, sometimes simultaneously ${ }^{(14)}$ 
Whereas for an individual, health can be assessed by an observer (usually a physician) who examines the individual and assesses their situation under different perspectives, health in a group or population requires a complex aggregation of data collected from its members. Furthermore, a continuous scale from "good" to "death" may be applicable for the individual, but a comparable scale cannot be applied to the group or population.

For many years, health measures for the population were almost exclusively based on mortality and life expectancy indicators. These have been used to evaluate the effectiveness of a given health system, and incorporate the quality and accessibility of services and other external factors. Although interesting as specific indicators of a given situation, these are insufficient as measurement units, because they can be influenced by factors unrelated to healthcare which compromises its validity and sensitivity.

Today, the evaluation of the health systems' performance, in the absence of a single health measure, still balances between two extremes ${ }^{(15)}$. On one hand, it is assumed that a set of positive attributes needs to be covered, although unequal and heterogeneous. These include: accessibility, property, amenities, competence, cost, efficiency, equity, patient centred, safety and promptness ${ }^{(12)}$. These, when properly combined, would ensure a perfect measurement mix. One by one would require various estimations and data difficult to obtain, transforming the operation into a complex and expensive task.

On the other hand, there stands the golden standard mythical "grail" that a single value would include all meanings. However, like all myths, practically, this is unattainable, "heavy" and not easy to manage.

As noted, this remains an open question ${ }^{7}$ and this is why it is important to highlight some summarized references, before trying to introduce a simple measure. Such a measure would be valued for its analytical potential and usability ${ }^{(16)}$. Thus, we will examine two of the most important publications on this matter.

The first one has had a deep impact that still resonates in health studies. We are referring to the World Health Report 2000 of the World Health Organization ${ }^{(17)}$ published in June 2000. This organization, one of the most respected UN agencies, published a ranking of its 191 members based on the overall performance of their respective health systems ${ }^{(18)}$ according to a set of unique and original measurements.

The report had a huge media impact, being discussed on the front pages of all newspapers and mainstream media around the world, because everyone wanted to know the position of the health system of their country as assessed by the United Nations health agency. multidimensional que envolve (às vezes ao mesmo tempo) aspetos físicos, emocionais e de satisfação social. ${ }^{(14) .}$

$\mathrm{Se}$, do ponto de vista individual, a saúde pode ser avaliada por um observador (normalmente um médico) que examina o indivíduo e qualifica a sua situação sob diferentes perspetivas, a saúde de um grupo ou de uma população exige uma agregação complexa dos dados recolhidos dos indivíduos que o ou a integram.

Só que, se para um individuo se pode construir uma escala contínua que pode ir de "bem" até "morto" não há escala comparável para um grupo ou para uma população.

Durante muitos anos, as medidas de saúde para as populações foram (quase exclusivamente) baseadas na mortalidade e na esperança de vida, indicadores utilizados para avaliar a efetividade de um dado sistema de saúde, procurando traduzir a qualidade das prestações e a acessibilidade aos serviços, bem como fatores externos. Sendo este tipo medidas interessantes como indicadores de uma situação de saúde, eram insuficientes como unidades de medida, até porque, podem ser influenciados por fatores alheios às prestações de saúde o que põe em causa a sua validade e sensibilidade rigorosa em casos concretos.

Hoje, a avaliação da performance dos sistemas de saúde, já que não há uma medida única da situação de saúde, ainda conhece algum balanço, entre dois extremos ${ }^{(15) .}$

De um lado e partindo do princípio que é necessário abranger um conjunto de atributos positivos embora de desigual importância e muito heterogéneos que incluem a acessibilidade, a apropriação, as amenidades, a competência, o custo, a eficiência, a equidade, a focalização no doente, a segurança e a prontidão ${ }^{(12)}$ que, devidamente combinados, garantiriam um mix de medidas quase indiscutível. Quando vistas uma a uma, têm que recorrer, quer a estimativas de peritos, quer a dados de obtenção difícil e a procedimentos de natureza complexa e cara para a sua operacionalização.

Do outro lado, o mítico "graal" do standard dourado, que num só valor encerraria múltiplos significados e, por isso, também ele, quase inatingível como todos os mitos, por "pesado" e de concretização pouco fácil.

Como se referiu, esta continua a ser uma questão ${ }^{7}$ aberta pelo que é importante antes de apresentar uma medida que se procura simples, valorizada pelas suas potencialidades mas também pela sua facilidade de execução apontar, ainda que sem grandes desenvolvimentos, algumas referências, se possível ainda ativas que ajudem a balizar o percurso que esta questão continuará a seguir ${ }^{(16)}$.

E, nesta perspetiva, optou-se por apresentar duas das mais relevantes "pegadas" que o percurso feito regista.

A primeira que não é possível deixar de referir pelo profundo impacto que teve e continua a ter nesta matéria é o World Health Report de 2000 da Organização Mundial de Saúde ${ }^{(17)}$ (publicado em Junho de 2000) e no qual, pela primeira vez, esta organização (uma das mais respeitadas agências das Nações Unidas), publicou no seu relatório anual uma lista ordenada dos seus 191 membros que visava classificar a performance em geral do respetivo sistema de saúde ${ }^{(18)}$ segundo um conjunto único e original de medidas.

O Relatório teve um enorme impacto e foi discutido na 
Presumably, the evaluation intention was to establish "best practice" to be used as an example in the achievement of better health.

The rank was based on three types of mixed indicators (19), (20):

- $\quad$ The first had to do with the effectiveness of the health system (mostly medical care and traditional public health services);

- $\quad$ The second was related to the system's ability to protect users' dignity, ensuring confidentiality, choice of providers, response promptness, ensuring adequacy of social support and the level of amenities. This might be briefly described as the responsiveness capacity (a combination of patient satisfaction with the system's performance quality) or "general responsiveness";

The third type of indicators were associated with the system's fairness, mostly measured by the care financing evolution, relating the user economical capacity to the requested financial effort ;

These three types of indicators were considered and added to create a single performance indicator ${ }^{(20) ;}$

But multiple criticisms were immediately pointed out ${ }^{(19)}$. Countries that were not considered as success models were highly ranked, while others, usually recognized were modestly ranked. Among industrialized countries, France, Italy and Spain were among the best "performers". However, Canada, Germany Sweden and Denmark, often cited as models by experts, were placed in modest positions. The United States was ranked in the 37th and last position amongst industrialized countries, and Greece, Portugal and Ireland who spent (and still spend) a much smaller portion of their wealth on health, were ordered in much better positions.

The main set of criticisms focused on the methods and other technical aspects mostly related to both the clarity and validity of the rankings. They also questioned the comparability of all WHO member countries, as some could not even provide basic information, and relied on estimated values. Moreover, the report was also accused of the uncritical prime status assigned to the individualized care culture for which there was no unquestioned evidence relating this to effective reduction of morbidity and mortality. Other primeira página de todos os jornais e nos principais media no mundo inteiro pois toda a gente queria saber qual a posição do sistema de saúde do seu país na avaliação da agência para a saúde das Nações Unidas.

Presumivelmente, a ordenação divulgada com base na avaliação da performance dos sistemas de saúde, tinha por objectivo estabelecer quais "os melhores" para que, depois, pudessem servir como exemplo a caminho de uma saúde melhor.

A ordenação realizada fundava-se em três tipos de indicadores, todos eles compostos ${ }^{(19),(20)}$.

- O primeiro tinha a ver com a efetividade do sistema de saúde (sobretudo cuidados médicos e serviços de saúde pública tradicionais).

- $\quad$ O segundo estava relacionado com a capacidade do sistema proteger a dignidade dos utilizadores, garantindo confidencialidade, escolha dos prestadores, respondendo com prontidão e assegurando nível adequado de apoio social e de amenidades. Resumidamente o que se poderá designar por capacidade de resposta (uma combinação de satisfação dos doentes com a qualidade de atuação do sistema) ou nível geral de "responsiveness".

$\mathrm{O}$ terceiro tipo de indicadores estava associado à justiça do sistema, medida em boa parte pelo grau de progressividade do financiamento dos cuidados, relacionando capacidade económica do utente com o esforço financeiro que the era solicitado;

Estes três tipos de indicadores eram ponderados e adicionados para criar um indicador único de performance ${ }^{(20)}$, mas críticas de diferentes ordens choveram de todos os lados ${ }^{(19)}$

Ordenados em posição elevada que habitualmente lhes não era reconhecida apareciam países que não eram qualificados como modelos de sucesso. E, em contrapartida, outros mais respeitados receberam ordenações bem mais modestas.

De entre os países industrializados, França Itália e Espanha ficaram entre os melhores "performers". Mas, o Canadá, a Alemanha a Suécia e a Dinamarca muitas vezes citados como modelos por muitos peritos, tiveram ordenações mais fracas.

Os Estados Unidos foram colocados na $37^{\mathrm{a}}$ e última posição entre os países industrializados e a Grécia, Portugal e a Irlanda que gastavam (e gastam) uma parte bastante menor da sua riqueza em saúde, ficaram ordenados em posições bem melhores.

O principal conjunto de críticas incidiu sobre os métodos utilizados e outros aspetos técnicos relacionados, quer com a clareza e com a validade dos rankings, quer sobre a comparabilidade de todos os países membros da OMS,
${ }^{7}$ We should also remember that it is an issue related to the (electronic) medical register and clinical data processing. These are over-the-edge domains, revealing the fast level of advances, which promise, in the short term, new consolidation steps.

${ }^{8}$ Burden of disease: a concept developed with the support of the World Health Organization and the World Bank that combines information about loss of quality of life with another on morbidity and mortality.

${ }^{9}$ In terms of the health status of the population, are we better or worse today than yesterday?

Are we better or worse than countries that spend as much as us?
${ }^{7}$ Assinale-se que é uma questão associada aos avanços no registo (eletrónico) e tratamento da informação de natureza clínica. área que conhece um progresso exponencial que promete novos passos e consolidados e a curto prazo

${ }^{8}$ Burden of disease" um conceito desenvolvido com o apoio da Organização Mundial de Saúde e do Banco Mundial que combina informação sobre perda de qualidade de vida com outra sobre morbilidade e mortalidade

${ }^{9}$ Em termos de situação de saúde da população, hoje estamos melhor ou pior do que ontem?

Estamos melhor ou pior do que os países que gastam tanto como nós? 
accusations, sometimes not so evident, followed. For example, with reference to the methodology, this eventually favored some institutional frameworks such as privatization, competition and "managed care" ${ }^{(20)}$. It was also argued that the press release suggested that there had been direct participation of the population in establishing the rankings, although in fact no citizen or patient was interviewed. In reality, a questionnaire was given to public health experts, many of whom did not even reside in the countries in the survey of "responsiveness" evaluation ${ }^{(20)}$. Two surveys conducted in Canada and the United States for the Harvard School of Public Health were also used.

Another controversial issue concerned whether or not public satisfaction and some of its segments (the poor and the elderly). should be measured. Especially because some countries, surprisingly highly ranked (Italy and Spain) had produced, almost simultaneously, satisfaction surveys of their patients, with results far less than satisfactory.

During discussion a fundamental question remained unresolved. Who is best fitted to assess health systems public health experts or the population that uses these systems? ${ }^{(18)}$. This question is still unanswered and remains on the agenda.

In fact, two papers recently published, showed controversial conclusions for different reasons and reopened discussion:

The Gallup survey released last April. This employed a " users perception " to evaluate their confidence regarding the health care quality in their residential location compared with the confidence felt regarding their respective national system ${ }^{(23) .}$

The "Euro Health Consumer Index 2012". This was published by the Health Consumer Powerhouse ${ }^{(24) .}$ It aims to compare health systems' performance based on the users' perception, providing more comprehensive results.

These studies, in particular the latter, have generated a wide discussion.

Ten years later, the controversy has diminished but is far from being over. Even if the WHO does not publish any other ranking, their path breaking work should be applauded. However, some of the criticisms remain valid, such as insufficient preparation and lack of consensus prior to this extremely complex task ${ }^{(24)}$. Regarded, even today, as a remarkable initiative ${ }^{(24)}$, the World Health Report 2000 definitely placed the assessment of health systems' performance on the Health Policy and Administration agenda.

The second, although not the least important reference is The Disability Adjusted Life Years (DALYs). This is a measurement unit originally developed by Harvard alguns dos quais no quadro de uma generalizada exigência de informação mais ou menos sofisticada, nem sequer disporiam de alguma informação básica, obrigando ao recurso, com frequência, de estimativas

Por outro lado, o Relatório era acusado de reproduzir de modo acrítico a afirmação da cultura dos cuidados médicos individualizados para a qual não havia nem há indiscutida evidência de que a prestação de cuidados é muito efetiva na redução da morbilidade e da mortalidade.

Isto, para além de acusações mais ou menos veladas da metodologia privilegiar determinados procedimentos (a privatização, a competição ou os "managed care") ${ }^{(20)}$.

Por outro lado e embora a forma como a comunicação à imprensa foi feita pudesse sugerir uma participação direta das populações no estabelecimento da ordenação, nenhum cidadão ou doente foi entrevistado.

Houve sim um inquérito em que participaram peritos em saúde pública, muitos dos quais não residiam nos países cuja capacidade de resposta estavam a julgar ${ }^{(20)}$.

Também foram utilizadas as respostas de dois inquéritos realizado no Canadá e nos Estados Unidos para a Harvard School of Public Health.

A utilização para este efeito da valorização ou não valorização da satisfação do público e de alguns dos seus segmentos (pobres e idosos) também entrou na polémica acesa que se gerou sobretudo porque em alguns dos países colocados surpreendentemente no topo da ordenação (Itália e Espanha), tinham feito quase simultaneamente inquéritos de satisfação aos seus utentes, com resultados bem menos satisfatórios.

Pairando sobre toda a discussão estava uma questão de fundo que a complexidade do método e dos procedimentos utilizados por vezes não conseguiu apagar e que sob várias formas, renasce a cada passo. Quem é que está mais qualificado para apreciar os sistemas de saúde: peritos de saúde pública ou a população que recorre e usa a esses sistemas? ${ }^{(18)}$. A questão continua sem resposta e a discussão continua na "ordem do dia".

De facto, ainda muito recentemente dois trabalhos, controversos nas suas conclusões (por diferentes razões) suscitaram a reabertura da discussão:

- Um questionário da Gallup divulgado em Abril passado procura utilizar a "perceção dos utentes" para comparar a sua confiança na qualidade dos cuidados de saúde na sua área de residência com a confiança que lhes merece o sistema a nível nacional em que estão inseridos ${ }^{(23)}$.

- $\quad$ Outra, com um alcance mais vasto decorre da Health Consumer Powerhouse, ter publicado o "Euro Health Consumer Index $2012^{(24)}$ que tem por objetivo estabelecer uma comparação da performance dos sistemas de saúde baseada na perceção dos utilizadores.

Estudos que (sobretudo o segundo) estão a suscitar uma larga discussão

Dez anos volvidos, a polémica está esbatida mas não encerrada e, sendo certo que a OMS não voltou a publicar outro ranking, sublinha-se a coragem da atitude mas também a fraqueza da reduzida preparação e a falta de criação de consensos prévios ${ }^{8}$ para uma tarefa extremamente complexa 
University for the World Bank (1990) and subsequently (in 2000). It has been adopted by the WHO to describe quantitatively the disease burden ${ }^{8}$, using both morbidity and mortality to facilitate comparisons with all types of health outcomes. ${ }^{(15),(25)}$. DALYs might also facilitate the cost - benefit analysis on alternative interventions and future projections about the evolution of the disease burden. DALYs are designed to measure the reduction in the quality of life resulting from disability and premature mortality. This is a problematic methodology, because it demands the use of many assumptions and expert estimations in order to obtain data and to calculate the disability indicator. Without the use of such assumptions some commentators claim DALYs would have crumbled. The development of this method is usually attributed to Murray and Lopez ${ }^{(26) \text {, }}$ (27)

The adoption of DALYs as a unit of measurement represented a significant step forward. Twenty years later it still remains a major tool in the assessment of health systems' performance, health policy and administration. However, in a panorama dominated by mortality rates, early criticism questioned the validity of the DALYs' data and the methodology applied (28), (29), (30) (31). It was affirmed that even the authors were fully conscious about data limitations, believing that the application would contribute, alongside the test, to improve the method.

Criticism was to be expected given the impact that new and revolutionary procedures and methodologies always evoke, even in advanced science and technology areas. Part of the criticism was that the DALYs calculation was too expensive and required too much time. The argument maintained that this would have particular impact on countries with more limited resources.

In other words, there is a continued increase in support of the move towards a generalization of the assessment procedures and analysis tools which assess health systems' performance. Furthermore, undoubted progress in methodology and information has been achieved by DALYs. However we still have not got a process allowing for a systematic widespread evaluation of health systems' performance. Returning to the presented questions ${ }^{9}$ it was felt that an appropriate method should be found and, without unreasonable expense, promptly implemented. The DALYs is more ueful than the WHO methodology used to establish the 2001 ranking, as DALYs allows us to obtain answers to many of the fundamental requirements for a useful index..DALYs is clear and technically secure despite some reservations regarding response time ${ }^{(32)}$, justifying further attempts to find a measurement unit and an assessment model.
(24). Tendo sido uma iniciativa considerada como notável, qualificação que se mantém ainda hoje ${ }^{(24)}$, na agenda da política e administração da saúde reconhecendo-se ao World Health Report 2000, o mérito de ter definitivamente colocado na agenda da Política e Administração da saúde a questão da avaliação dos sistemas de saúde ${ }^{9}$.

A segunda mas não menos importante das referências a fazer, diz respeito aos Disability Adjusted Life Years (DALYs) uma unidade de medida desenvolvida originalmente pela Universidade de Harvard para o Banco Mundial (em 1990) e que, subsequentemente, (em 2000) a OMS adotou para descrever quantitativamente o peso da doença, recorrendo simultaneamente à morbilidade e à mortalidade e facilitar comparações com todos os tipos de resultados de saúde. ${ }^{(15),(25)}$. O DALY facilita ainda as análises custo benefício em intervenções alternativas e as projeções sobre a futura evolução do "peso da doença" .

Os DALYs são construídos a partir da qualidade de vida reduzida por incapacidade e por mortalidade prematura. Trata-se de uma metodologia exigente com recurso que alguns julgam excessivo à intervenção de peritos e a estimativas, quer na obtenção de dados, quer na utilização desses dados, isto é, no cálculo do indicador, designadamente no domínio da incapacidade. A ponto de ser afirmado que sem este tipo de intervenção a ideia dos DALYS se teria esboroado. Murray e Lopez são geralmente apontados como os principais responsáveis pelo desenvolvimento do método ${ }^{(26),(27)}$.

Trata-se de um substancial avanço que marcou uma época e que hoje, vinte anos volvidos, continua a ser uma referência maior da avaliação da performance dos sistemas de saúde mas também da área de política e administração de saúde. No entanto, num panorama dominado pela mortalidade, cedo surgiram críticas sobre diferentes aspetos dos dados requeridos pelos DALYS e da metodologia que utilizavam ${ }^{(28),(29),(30)(31)}$.

Afirmando-se até que até os autores principais do método tinham consciência das limitações dos dados mas que apostavam em que as suas sucessivas aplicações para além de os testar, iriam aperfeiçoar a metodologia da sua obtenção.

Críticas que devem ser entendidas no contexto do impacte que procedimentos novos e arrojados do ponto de vista metodológico sempre têm mesmo em áreas consideradas de ponta no domínio técnico e científico.

Uma parte das críticas concentrou-se no custo dos recursos e no tempo requeridos para cálculo do "peso da doença em DALYS e para as necessárias análises de custo efetividade. Outros consideravam que o cálculo dos DALYS, para além de ser caro e de exigir muito tempo, afirmando ser duvidoso que em países de recursos escassos se consigam afetá-los em procedimentos complexos e para muitos pouco compreensíveis.

Isto é, apesar de continuarem a crescer os que defendiam o avanço no sentido da generalização dos processos de avaliação e dos instrumentos de análise que permitam conhecer a performance dos sistemas de saúde e apesar do inquestionável avanço (metodológico e informativo) que os DALYS propiciaram, ainda não foi esta via que banalizou o processo e permitiu a avaliação generalizada e sistemática da performance dos sistemas de saúde. Por outras palavras e 
Choosing a measure to quantify a population health status, or to compare the situation of different populations has long been discussed and pursued with remarkable results in terms of acquired knowledge. However, this knowledge, which should produce a fast, systematic, and economic operational impact, has failed to show significant and relevant results.

In the XXI century it is still not easy to assess objectively a health system performance or its efficiency or effectiveness. Not for knowledge failure or adequate procedures but because either the procedures, or data needed, are not available or easy to access, and require skills and resources that most systems don't possess. However, several researchers and various organizations (some of them with powerful features) have worked on trying to developing new metrics over the years, conscious about the need to find simple but essential answers to ensure the correct functioning of health systems.

In the early 1980s of the last century, the Center for Disease Control (CDC), a United States federal agency based in Atlanta, Georgia, was specifically dedicated to promote a population's health protection and safety, through information collection and dissemination that helps to optimize and improve health decisions, and to promote cross-cooperation between states, the Federal Government and its Departments. It started developing a growing interest in the circumstances of preventable deaths, with various objectives, from reducing early death due to health care failure, to reduction of the disease burden (in general terms or related to certain specific causes) (33) (34.).

Mortality statistics have been used to (i) quantify the extent of health problems, (ii) determine the relative importance of various causes of death and (iii) to add rigour to objectives and priorities processing in health.

The "crude" mortality analysis even when adjusted by factors such as age, traditionally played a crucial role in this process by allowing goals and priorities to be set and their monitoring later.

But this measure overemphasises the importance of the elderly in the population since this group includes most of the deaths. Under this context and after further testing using adjusted mortality rates in the population ${ }^{(33)} \mathrm{CDC}$ began to develop the process for measuring the potencial years of life lost (PYLL) ${ }^{(35)}$ culminating in 1982 with the recognition by CDC of PYLL as a suitable indicator. In contrast to the retornando às questões ${ }^{10}$ que se considerou deverem poder ter resposta apropriada, segura e operacionalizada com prontidão e sem custos desproporcionados, resulta do que ficou dito que, mais até do que a metodologia usada pela OMS na construção do seu ranking de 2001, os DALYS viabilizam respostas que respondem a alguns desses requisitos.

Dão-lhes resposta claramente apropriada e tecnicamente segura, registando-se no entanto algumas reservas quanto à prontidão da resposta e aos custos que determinam pelos recursos que mobilizam ${ }^{(32)}$, justificando novas tentativas para encontrar uma unidade de medida e um modelo de avaliação mais próximos dos que foram sendo apontados como necessários.

Mas, se escolher uma medida para quantificar a situação de saúde de uma população ou para comparar a situação de diferentes populações, tem sido um objectivo longamente debatido e perseguido com resultados assinaláveis no plano do conhecimento adquirido, os resultados obtidos do ponto de vista da disponibilidade desse conhecimento para uma operacionalização ágil, económica e sistemática, têm sido francamente menos relevantes.

Assim, em pleno século XXI continua a não ser fácil avaliar objetivamente a performance de um sistema de saúde ou a sua eficiência ou efetividade, não por falta de conhecimento ou de procedimentos apropriados mas porque, quer os procedimentos, quer os dados requeridos, são pouco acessíveis ou, exigem uma disponibilidade e uma perícia que na maior parte dos sistemas não existe em permanência.

Isto, apesar de ao longo dos anos e conscientes da necessidade de encontrar respostas para perguntas simples mas essenciais para o bom funcionamento dos sistemas de saúde, vários investigadores e diversas organizações (algumas delas com poderosos recursos) terem apostado no tema e na ultrapassagem das limitações técnicas então existentes, desenvolvendo novas métricas.

No início da década de 80 do século passado, o Centro para o Controlo da Doença (CDC) a agência federal dos Estados Unidos, sediada em Atalanta (Geórgia) e especialmente incumbida de promover a proteção da saúde e da segurança das populações, designadamente através da obtenção e divulgação de informação que otimize e melhore a decisão no domínio da saúde e promova a situação de saúde através do fomento da cooperação transversal entre os governos estaduais e o Governo Federal e os seus Departamentos, começou a desenvolver um interesse crescente sobre as situações de morte evitável, com diversificados objectivos que iam desde a redução das mortes prematuras por falta de apoio de cuidados de saúde até à redução do chamado "fardo da doença" (burden of disease") em geral ou tendo como origem determinadas causas ${ }^{(33)(34)}$.

As estatísticas de mortalidade tinham sido frequentemente utilizadas para (i) quantificar a dimensão dos problemas de saúde, para (ii) determinar a importância relativa das várias causas de morte e para (iii) tornar mais rigoroso o processo

\footnotetext{
${ }^{10}$ Also in Portugal, PYLL has recently received great attention, both through its inclusion in the basic indicators released by the General Directorate of Health ${ }^{(43)}$, and through INE publications ${ }^{(44)}$ that explore some interesting variables (mostly causes of death).

22
}

${ }^{10}$ Também em Portugal, os APVP têm recebido recentemente a maior atenção, quer através da sua inclusão na coleção de indicadores básicos de saúde publicada pela Direção Geral de Saúde ${ }^{(43)}$, quer através de publicações do Instituto Nacional de Estatística ${ }^{(44)}$ que explora algumas variáveis interessantes (sobretudo causas de morte 
conventional mortality valuing all deaths in the population (36), PYLL gives greater weight to deaths at younger ages. It is a simple calculation process that can be easily adjusted between limits appropriate to the application objectives (36), ${ }^{37 .)}$

Premature deaths are often referred to as those deaths occurring before age 65 years. However, different limits may be set if justified by the study objectives and purposes (considering gender, ethnicity, given morbidity, etc.). In fact there is still an open debate about limits in order to be able to compare studies. Some suggest an approximation between the maximum age of life expectancy at birth, to the date of death or to the life expectancy without disability ${ }^{(38 .)}$. It is also possible to establish a minimum and a maximum (as an example to include only lost years between ages 15 and 65). Thus, a reference to the value of life at a given age for a given goal may be introduced.

The use of PYLL, shows some advantages and disadvantages.

Advantages:

- $\quad$ it values more deaths in younger ages, so reduction should be an important goal of health systems. Also because these are often assigned to preventable causes, and when detected, easily allows intervention and prevention

- the intervention is socially and economically rewarding.

- $\quad$ it might be used for a whole population or only to a given disease or cause of death.

- $\quad$ Finally, we shall recall that PYLL may be adjusted to the population (100000 or 1000) to age, gender, race, etc..

Disadvantage:

The main disadvantage is that PYLL only considers deaths within the chosen age boundaries, which requires that those limits are explicitly predefined. de definição de objetivos e prioridades em saúde.

A análise dos valores da mortalidade "bruta" ou ajustada por vários fatores, designadamente pela idade, desempenharam tradicionalmente um papel crucial nesse processo permitindo, não só estabelecer objetivos e prioridades mas também monitoriza-los depois.

Mas, sendo importantes medidas (durante muitos anos quase as únicas) da situação de saúde das populações, essas taxas eram claramente insuficientes tendendo a sobrevalorizar a situação dos idosos já que era neste grupo que se situava a maior parte das mortes. Foi nesse contexto e depois de novos ensaios de utilização de taxas de mortalidade ajustadas à população ${ }^{(33)}$ que se começou a desenvolver o processo de valorização do indicador (APVP) ${ }^{(35)}$ que veio a culminar em 1982 com o reconhecimento pelo CDC dos APVP como um adequado indicador que, em contraste com as medidas de mortalidade convencionais, valorizava todas as mortes ocorridas na população ${ }^{(36)}$ mas que dá um peso maior às mortes ocorridas em idades mais jovens. E um processo de cálculo acessível que pode ser ajustado facilmente entre limites adequados aos objetivos da sua utilização ${ }^{(36),(37) .}$

Se com frequência se consideram-se mortes prematuras o ocorrido antes dos 65 anos, nada impede, no entanto que a idade limite utilizada para o cálculo e por razões justificadas pelo objetivo do trabalho (sexo, etnia, uma dada morbilidade, etc.) possa ser outra. Permanecendo aberto um debate sobre qual o limite que deve ser eleito para que estudos em geral possam ser comparáveis, há quem encoraje uma aproximação da idade limite da esperança de vida à nascença, à data da morte ou mesmo da esperança de vida sem incapacidade

Também é possível estabelecer um limite mínimo (só contarem, por exemplo os anos perdidos entre os 15 e os 65 anos). Podendo assim incluir uma referência ao valor da vida numa dada idade para um dado objetivo.

A utilização dos APVP, apresenta vantagens e desvantagens.

Como vantagens:

Valoriza mais as mortes nas idades mais jovens, cuja redução deverá ser um importante objetivo dos sistemas de saúde até porque são frequentemente atribuídas as causas passíveis de prevenção, o que, quando detetadas permite mais facilmente intervenção e prevenção,

- $\quad$ A intervenção é social e economicamente mais compensadora.

- Pode ser utilizado para toda uma população ou apenas para uma dada doença ou causa de morte.

Finalmente, recorde-se que os APVP podem ser ajustados à população (100000 ou 1000) à idade, ao género, à raça, etc.

A principal desvantagem, reside no facto de só contar as mortes que se situam dentro dos limites etários estabelecidos o que torna absolutamente necessário explicitar claramente esses limites. 


\section{Conclusions}

In summary, despite the existence of multiple measures to quantify the health status of a population and to evaluate the evolution of health systems performance, PYLL is actually considered to be the most appropriate measure ${ }^{(39),(40),(41),(42)}$, especially considering the excellent relationship between the resources involved and

\section{Conclusões}

Em resumo, apesar da existência de múltiplas medidas para quantificar a situação de saúde de uma população e avaliar a evolução da performance de sistemas de saúde, hoje considera-se esta medida como das mais apropriada (39), (40), (41), (42), sobretudo tendo em consideração a excelente relação entre os recursos que envolve e os resultados que propicia.

Table 4 - European Union Countries, PYLL (man) Evolution 1990/2008

Tabela 4 - Países da União Europeia APVP (homens) Evolução 1990 /2008

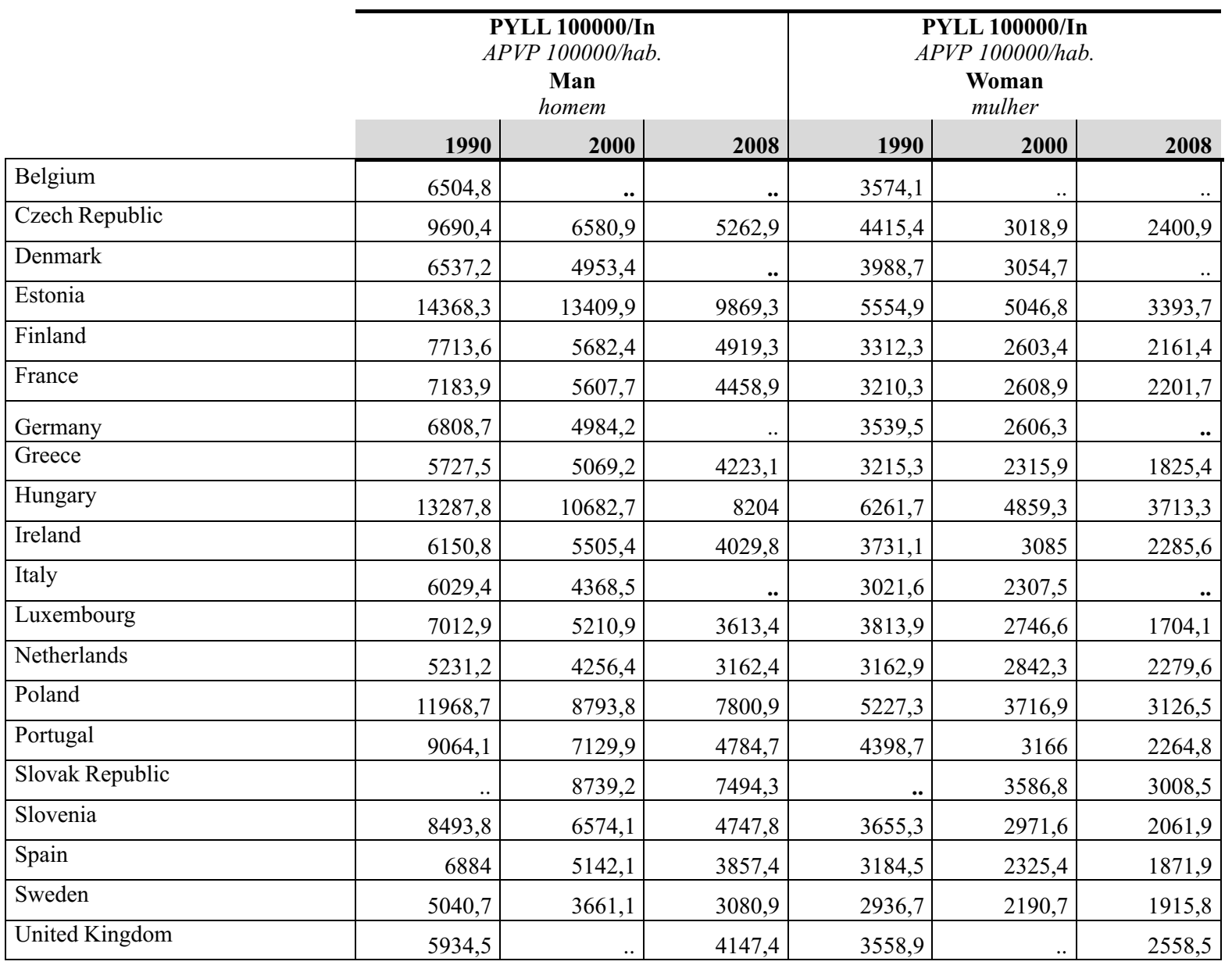

OECD, Health Data, 2011

Table 4 presents for EU countries, in the same time period used previously, the PYLL per 100,000 population aged from 0 to 69 years old.

We shall finally consider the two questions at the end of the second section to illustrate the difficulty in obtaining a straight answer. Considering Table 4 and the following Tables it seems possible to find some 24
A Tabela 4, apresenta para os mesmos países da União Europeia e para um período análogo os anos potenciais de vida perdidos (APVP) por 100000 habitantes entre os 0 e os 69 anos.

Para finalizar, valerá a pena considerar as duas questões que se utilizaram no final do ponto 2., para ilustrar a dificuldade de obter esclarecimento para elas. 
objective answers based on this data.

Questions were:

a) In terms of the population health status, is today's Portugal better or worse than yesterday?

b) Is Portugal better or worse than those countries with the same level of expenditure?

It is clear from Table 4 that there is a very substantial reduction in PYLL by 100000 inhabitants, with an asymmetry in "gender" favorable to women, which, incidentally, is common in our country. For women between 1990 and 2008, reduction of preventable deaths almost reaches $50 \%$ which is close to those of France and the Netherlands, and better than the United Kingdom.

For men, the reduction in PYLL is not as great as for women and identical comparable levels cannot be obtained. But looking further to this indicator PYLL, and if calculated by cause of death, profession, etc., it may help us to understand the reasons why there are these differences, both in the national and in the international levels. In any case, there is no doubt that in terms of health outcomes, we are better today than yesterday.

To respond clearly to the question in b) we should return to Table I and keep in mind that, according to this data, France and the Netherlands spend a larger proportion of GDP on the health sector compared to Portugal. The public and private components vary from country to country. Clearly, in terms of THE per capita in \$PPP, Portugal has spent much less than those two countries. And, however, in terms of outcomes (PYLL) Portugal stands at the same level as other countries which spend much more and record lower PYLL. That is, we are better than countries that spend more than Portugal and, apart from the two countries that we have quoted for comparison, the same is true also with others.

Without focusing specifically on the Portuguese case, it is clear that the increase in health expenditure has allowed health systems to provide better and longer life expectancy at birth, reduced disabilities, reduced child mortality (for 1000 living born ), and improved accessibility to health care. From a global perspective, it responded with improved health outcomes as shown by the reduction in PYLL (Table $4)$.
E ensaiar à luz dos dados da Tabela 4 e seguintes, abaixo apresentados, respostas objetivas e fundadas.

Questionou-se:

a) Em termos de situação de saúde da população, Portugal está hoje melhor ou pior do que ontem?

b) Portugal está melhor ou pior do que os países que gastam tanto como nós?

Quanto à alínea a) resulta da Tabela 4 que, há uma muito substancial redução dos APVP POR 100000 habitantes, com uma assimetria "de género" favorável às mulheres, o que, aliás, é comum no nosso pais.

Nas mulheres e entre 1990 e 2008, a redução das mortes evitáveis, é de quase de $50 \%$ ficando quase ao nível da França e da Holanda e melhor que o Reino Unido.

Quanto aos homens, não só a evolução é menor, como se não atingem patamares de comparação idênticos.

Sublinhe-se que este indicador (APVP) se aprofundado e calculado por causa de morte, por profissão, etc., pode facilitar resposta à inevitável questão sobre o porquê destas diferenças, quer a nível interno, quer em termos de comparações internacionais. Mas mesmo sem esse aprofundamento não há dúvidas de que, hoje estamos, em termos de resultados de saúde, melhor do que ontem.

Para procurar uma resposta objetiva ao questionado na alínea b) há que retornar à Tabela $\mathbf{I}$ e recordar que, segundo os dados ali apresentados, a França e a Holanda afetam à saúde uma parte da riqueza que produzem maior do que Portugal, variando a componente pública e privada de país para país. Mas, claramente e em termos de DTS per capita em \$PPPs, Portugal em relação a esses dois países tem gasto muito menos. E, no entanto, em termos de resultados (APVP) como se referiu está ao nível destes e de outros países que gastam mais do que nós, tendo menos APVP. Isto é, estamos melhor do que países que gastam mais do que nós e (para além dos dois países que citámos como comparação), o mesmo se verifica também com outros.

Sem focar especificamente o caso português, à indiscutível subida de despesas com a saúde não responderam apenas os respetivos sistemas com um prolongamento da esperança de vida, quer à nascença, quer livre de incapacidade e com a redução da taxa de mortalidade infantil (por mil nados vivos) ou com os acréscimos de acessibilidade apresentados. Agora numa perspetiva global que deve ser aprofundada e valorizada, respondeu com "ganhos em saúde" identificáveis através das substanciais reduções de APVP(Tabela IV). 


\section{References / Referências}

[1]Terries, M. - Winslow, C.-E.A WINSLOW scientist, activist and theoretician of the American public health movement throughout the first half of the twentieth century. J, Public Health Policy. 1998; 19(02):134-46

[2] PRIESTER, R. - A values framework for health system reform. Health Affairs, February, 1992. 11. 1.84-107.

[3] World Bank. Investment in Health. New York: Oxford University Press, 1993, 17-35.

[4] OECD (2011), Health at a Glance 2011:OECD Indicators, OECD Publishing. 23-46.

[5] Berman, P.; Pallas, S.; et alii; Improving the delivery of Health Services: A Guide to Choosing Strategies.The International Bank for Reconstruction and Development- The World Bank. Wa shington. 2011, pág 1-13. www.worldbank.org/hnppublications.

[6] Silim, A, - Wellbeing, Choice and sustainability: what should economic policy targey in a new era economy? Institute for Police Research, London, 2012, pag.7.

[7] Enthoven, A. Kronick, R. - A consumer-choice health plan for the 1990s. New England. Journal of Medicine. 1989; 320:29

[8] OECD - Health Data 2011. www.oecd.org/ff/?404

[9] Eurostat Healthy Life years statistics (April 2011)

.http://epp.eurostat.ec.europa.eu/statistics_explibed index.php?title $=\mathrm{He}$.

[10] LEE, T. Putting the value framework to work. N Engl J. Med. 2010, 363, 2481-2483. December 23, 2010.

[11] Lockart, C. Values and policy conceptions of health policy elites in the united States, the united Kingdom and the Federal Republic of Germain.Journal of Health Politics, Policy and Law.15;: 129-143.

[12] King's Fund Measuring NHS Success. January (2005) King's Fund Publications:3-11. http://www.kingsfund.org.UK/

[13] Berenson, E.R.A How does quality of US Health Care Compare Internationally? Urban Institute:August (2009):5-11.

[14] Peacock, S.; Chan, C. Mangolini, M. Jhansen, D. - Techniques for Measuring Efficiency in Health Services. Commonwealth of Australia. Belconnnen, (2001). Pág. 1-11.Available in www.pc.gov.au.

[15] Murray, C. Assessing health systems performance using information on effective coverage of interventions. University of
Queensland, Working Paper Series, $\mathrm{n}^{\circ}$ 3, November 2009.6-9.http://www.uq.edu.au/histhub.

[16] LEICHTER H.; TRYENS, J. - Achieving bette health outcomes : the Oregon benchmark experience. Milbank Memorial Fund, (2002) New York (NY) http://econ,stateor.us/opb

]17] World Health Organization, World Report 2000 (Geneva: World Health Organization 2000), 24 http://www.who.int/whr/2001/archives/2000/en/ind ex.htm.

[18] Blendom, J., Benson, JM, Kim, M. The Public versus the W00rld Health Organization on Health Syst em Performance. Health Affairs, May 2001 vol. $20 \mathrm{n}^{\circ} 310-20$.

[19] Navarro, V. Assessment of the world Health Report 2000.Lancet. 2000;356:1598-1601

[20] Navarro, V. The World Report 2000:can Health Care Systems be Compared Using a Single Measure of performance? Am J. Public Health. V.92 (1); Ja1993n. 2002 31-34

[22] Brown, IT, Khoury, C In OECD Countries, Universal Healthcare Gets High Marks. (17 April 2012). http://gallup.com/poll//122392//oecd -countries-universal-healthcare-gets-high-marks

[23] Health Consumer Powerhouse Euro Heath $\begin{array}{lllll}\mathrm{C} \text { on s u m e r I n e x } & 20 & 0 & 12\end{array}$ Report.www.healthpowerhouse.com.

[24] MCKee, M. The World Health Report 2000:10 years on. Health Policy and Planning 2010 $25: 346348$

[25] Fox-Rushby, JA Disability Adjusted Life Yeats (DALYs) For Decision Making? An overview of the citerature. London: Office of Health Economics 2002, 47-63.

[26] Murray, CJL, Lopez AD (1994b) Quantifying disability: data methods and results, In Murray, CJL, Lopez AD (eds) (1994a) Global Comparative Assessment in the Health Sector: Disease Burden, Expenditures and Interventions World Health Organization, Geneva, 55-96.

[27] Murray, CJL, Lopez AD (1994a) Global Comparative Assessment in the Health Sector Disease Burden, Expenditures and Interventions World Health Organization, Geneva.

[28] Fox-Rushby, JA Disability Adjusted Life Yeat (DALYs) For Decision Making? An overview of the literature. London: Office of Health Economics 2002, 82-84.

[29] Paalman M, Bekedam H, Hawken L, Nyheim D (1998) A critical review of priority setting in the health sector: the methodology of the World Development Report. Health Policy and Plan 13,1,
13-31.

[30] Lopez AD (1990) Who dies of what? A comparative analysis of mortality conditions in developed countries around 1987, Rapp Trim Stat Sanit. Mondiales 43,2, 91-104

[31] Murray CJL (1990) Rational approaches to priority setting in international health. J Trop Med Hyg. 93, 5, 303-311

[32] Fox-Rushby, JA Disability Adjusted Life Yeats (DALYs) For Decision Making? An overview of the literature. London: Office of Health Economics 2002, 95-99.

[33] Gardner JW, Sanborn JS. Years of potential life lost (YPLL) - what does it measure? Epidemiology, 1990; 1(4):322-329.

[34] CDC. Introduction to Table V: premature deaths, monthly mortality and monthly physician contacts. United States. MMWR 1982; 31:109-10, 117.

[35] Haenszel W. Standardized rate for mortality defined in units of lost years of life. Am J Public Health 1955; 40: 17-26.

[36] Perloff JD, et alii. Premature death in the United States :years of life lost and health priorities. J Public Health Policy 1984; 5: 167-84.

[37] Elen Nolte; Martin McKee. Measuring the health of Nations: analysis of mortality amenable to he a $1 \mathrm{th} \quad \mathrm{c}$ are. B M J $2003 ; 327$ : 1128.http://www.bmj.com/content/327/7424/1129. [38] Association of Public Health Epidemiologists in Ontario. Calculating Potential Years of Life Lost (PYLLhttp://www.apheo.ca/index php?pid=190.

[39] McDonnell S, et alii .Using YPLL in health planning. Public Health Reports 1998; 113: 55-61.

[40] Mckee M Measuring the efficiency of health systems. BMJ 2001; 323:295-6.

[41] Marshall RJ Standard expected years of life lost as a measure od mortality: norms and reference to New Zeland data. Aust NZ J Public Health 2004, 28 (5); $452-457$

[42]Aragón TJ et alii. Calculating expected years of life lost for assessing coca ethnic disparities in cause of premature 1death.BMC Public Health 2998, 8: 116. http://www.biomedcentral.com/com/1471 2458/8/116.

[43] Direção Geral da Saúde. Portugal Saúde: Indicadores básicos, 2005. DGS, Lisboa, 2008 51-52 [44] Instituto Nacional de Estatística. Detalhe, 2009. $\mathrm{http} / / \mathrm{metaweb}$.ine.pt/sim/conceitos/Deatalhe.Aspx ?cnc $\operatorname{cod}=7252 \& \mathrm{cnc} \ldots$ 